\title{
Manuel de Pedrolo: Literature as Intellectual Engagement
}

\author{
Xavier Ferré Trill ${ }^{*}$ (Department of Pedagogy of the Universitat Rovira i Virgili) \\ xavier.ferre@urv.cat ～http://orcid.org/ 0000-0002-8042-1184
}

\begin{abstract}
The article lays out the conceptual bases that Manuel Pedrolo developed -in the form of philosophical literature- in a section of his narrative. I describe the directionality of the author's intellectual program with regard to the 'double liberation' in detail. The interest of the work lies in exposing the inherent limitations of 'literature for literature' -with disregard of human nature- that can also be applied to any international literature, not only written in the fifties and sixties, but in the (ideologically) present time.
\end{abstract}

Keywords. Philosophical literature, double liberation, human nature.

\section{Introduction}

The writer Manuel de Pedrolo i Molina (L’Aranyó, 1918-Barcelona, 1990) stated that life meant work $^{1}$; that is, his literature is the result of his stylistic and political engagement. For Pedrolo, literature was necessary for understanding oneself and for understanding the individual's place in the world, which meant that his work went beyond genres to express a "continuity of thought". This meant an attitude of engagement when narrating and interpreting the defining circumstances of characters that represent a social context that is often adverse to the human condition. Such engagement tempered the internal laws of literary expression that were supposed to regulate a narrative text. Pedrolo would not accept this conditioning if, as was often the case, the most important element of a work was supposed to be its sociological content. Nevertheless, the predominant element was the writer's biography:

Even if a writer wanted to write a work that was "solely" artistic, he would do it with certain conditioning, he would be pressured by his conditioning, which he would either accept or fight, but which is nevertheless there. ${ }^{2}$

Pedrolo described the act of writing to the writer Josep Vallverdú; it put him in a period between his youth and the trauma of the end of the Civil War, which must have conditioned him to sublimate this critical experience through literature. Writing, therefore, was a way out of a personal crisis caused by the post-war period; "I was

\footnotetext{
* Xavier Ferré Trill is tenured Senior Lecturer at the Department of Pedagogy of the Universitat Rovira i Virgili. He holds a $\mathrm{PhD}$ in Hostory and in Sociology. His research currently includes nation-building socio-political movements and political, sociological and literary thought.

${ }^{1}$ Letter from Joaquim Carbó to Jordi Arbonès (Barcelona, 22-XI-1982) in Arbonès, J., Carbó, J. (2014: 248).

${ }^{2}$ Regarding the expression "continuity of thought", see: Carles Isasi Angulo [ent.cit] in Pedrolo (1974: 204). For the rest of the paragraph, see: J. Coca $(1973: 54,90,151)$. The citation is on page 151.
} 
born to write, I had to write: I found anything that was not writing to be strange and remote". ${ }^{3}$ In what follows, I'll describe his deep political commitment with the act of writing as intellectual engagement, how he carried it on, and why.

\section{I work for something I feel that I have lost...}

In an answer to a questionnaire in 1966, Pedrolo made clear that dominant ideological principles tried to impose themselves on him, but that refused to be dominated. However, an artist or intellectual knew how to "find the cracks, force open the weak points that all human structures offer, and to build up a small following that will receive his work with a certain degree of expectation". It was an attitude that was evident when he tried to find meaning in the act of writing: "I work for something I feel that I have lost [...], I am working for it because I am here and I can't do anything to prevent it $[\ldots] " .{ }^{4}$

The desire to recover a lost reality explained why he imagined this time of reference through literature. When the philologist and critic Miquel Dolç (1968: 63) asserted that Pedrolo had invented a new reality he was referring to the act of substituting the present lived under Francoism (an official reality) for "another" (real) present prohibited by the dominant political regime. Literary imagination became a form of criticising the ideological model governing contemporary society. Pedrolo did not become a positivist author; instead, his expressive form depended on the capacity for the transvaluation or interpretation of situations that could apparently become "a-conflictive" or "neutral". The writer should not be a slave of facts, but should claim subjectivity as a creative resource. ${ }^{5}$

Pedrolo found this approach in the work of leading foreign writers. When reviewing the work of two writers with whom he identified, Samuel Beckett and Jack Kerouac, Beckett in particular stood out because his work did a "demolition job" on the bourgeois world by "destroying it from the inside" in order to build a "new society"; this highlighted an "uncomfortable truth" about the established order, whose values "tend to annihilate man" (Pedrolo, 1970: 51-52) ${ }^{6}$. In contrast, Kerouac exemplified criticism of the American way of life by immersing himself in oriental doctrines such as Zen Buddhism. Pedrolo also translated other foreign writers, such as the countercultural journalist and essayist Norman Mailer, whose work Cannibals and Christians (1966) was published as Fets de cultura (1971).

To what extent, however, did Pedrolo engage in this "work of demolition" and of "sweeping away" the hegemonic model of society in the 1960s?

Pedrolo demonstrates his ideological and political engagement through literature (it is his sole project). For him literature was life: in it he expressed existential causes rather than consequences. He based his work on negation, that is, on questioning the present state of things (Pi de Cabanyes, 2003: 132-133).

Although his writings adopted, on occasions, "generic" plots (as can be seen in Totes les bèsties de càrrega), the degree of intellectual criticism in his work often meant that the censor often delayed publication of his works. In a letter to Tomàs Tebé, the secretary of Josep Maria Cruzet at the Selecta publishing house, Pedrolo (Barcelona, 3-8-1956), states that:

\footnotetext{
${ }^{3}$ This recurring idea was expressed by Pedrolo in a letter to Josep Vallverdú (Barcelona, 26-VI-1967). He wrote the letter with regard to the article by Vallverdú "Manuel de Pedrolo a Tàrrega" (1967: 10). Another example can be found in the interview with Enric Calpena: "La totalitat narrativa", Diario de Barcelona, 5-XII-1980, p. 20. The citation is in "Avui es parla de mi (1991)", Garcia (1995: 35).

${ }^{4}$ Pedrolo (1974a: 39-40). The second citation is in M. de Pedrolo (1980: 139).

${ }^{5} 27$ October 1988, Pedrolo (1992: 251).

${ }^{6}$ Regarding Pedrolo's response to the "sudden awareness" among young Americans in the 1960s, see his introduction to J. Kerouac (Pedrolo, 1967: 6). For a list of the forty-one English and French works translated by Pedrolo between 1962 and (1994), see the entry 'Pedrolo i Sánchez de Molina, Manuel' at PijuanVallverdú (2011: 400-402).
} 
It seems that I am forever destined to deal with difficulties of all kinds, as if I was the black beast of Catalan literature. Incomprehension on the part of publishers (and not just Selecta), difficulties with the censor as you know, the antipathy towards me that I have generated for myself through my honest approach to my literature and my refusal to make concessions, the I-couldn't-care-less attitude of the critics, who think that they have made you happy and done their jobs when they offer a few rabid tributes that mean nothing ... it's a disgrace! I respond with resignation or impatience, depending on my mood at the time, but I also rue the day that I had the lucky chance to discover that I could write.

The publication of his works was prohibited because the censor had come to regard him as an "author nongrata", a situation that worried him because it meant that his work would lose its immediacy and appear dated by the time the public got to read it. Censorship is the reason for the lag between date of completion and the date of publication (Cisquella et al., 1977: 39-40). ${ }^{7}$

Pedrolo's approach to his work meant that the rules governing his expressive forms were less than conventional. This characteristic was marked by an existential philosophical perspective that sought a path to expression through narrative. Pedrolo's literary work had an overarching unity in its commitment to struggling against limits; that is, it is characterised by a desire to transcend self-limiting straightjacket of knowledge of the subject:

I use it [the word "existential"] because the problems that affect me are not exclusively intellectual nor aesthetic, but rather of a complete nature that compromises the mode of my being's commitment to contingency. Existential, in short, because only the man exists, because he only knows them to exist [...]. I am groping in the dark. I obey the force that I feel inside, an impulse of energy, unbridled, that threatens to overwhelm me, that knows no boundaries, but despite everything, creates them, because nobody can know how to be without limits. (Pedrolo, 1980: 198-199)

Despite the limits that Pedrolo alluded to, the existential crossroads faced by the individual (i.e. the coming) leads to the decidedly non-abstract real-life circumstances of man, a distinctive characteristic of Pedrolo's situational narrative: "Any human circumstance is important to me because it is my circumstance" (Capmany, 1957: 78). This fact, based, according to Pedrolo, on the philosophy of Sartre and Heidegger, meant "trying to be authentic within the inevitable and all-enveloping daily existence" (Clemente, 1966: 39).

Pedrolo was an exponent of "guiding literature", as opposed to "soporific literature", the two possible types mentioned by the critic and writer Arnau Puig when commenting on the narrative of Fèlix Cucurull. Compared with Cucurull, Pedrolo's work is an analysis of reality devoted to highlighting the degrees of human alienation "in a society in decomposition". In this regard, the writer Robert Saladrigas, when contextualizing Fèlix Cucurull, considers the defining moment to be the break-out of the Civil War and the arrival of Sartre's existential philosophy. ${ }^{8}$ Cucurull, like Pedrolo, regarded himself as a member of the "generation of the disaster" (Vidal i Gayolà, 1968: 8). Both of them were alive at the end of the 1940s and the beginning of the 1950s when they had collections of poetry published by the Torrell publishing house in Reus, namely Vida terrena (1948) and Ésser en el món (1949), each one clearly influenced by existentialism. ${ }^{9}$ Both men were also involved in the struggle for national liberation, Cucurull through historiography ${ }^{10}$ and Pedrolo through political criticism.

\section{The Role of the Media}

\footnotetext{
${ }^{7}$ This volume is in the personal library of the author. See also the letter from Pedrolo to Josep Faulí (Barcelona, 18 June 1972), in Garcia (1997: 660).

${ }^{8}$ Puig (1963), Saladrigas ([1977], 1986: 44-48).

${ }^{9}$ The journal Ressò headed by the priest Ramon Muntanyola was the first to circulate existential poems by both authors (works which remain unpublished) in the section "Marges vius", and in the epigraph "Dos poetes front a font". The poems in question were "Inútil recerca" and "Pelegrins de l'eterna aventura" by Fèlix Cucurull and "Existència" by Pedrolo. See Ressò. Cròniques i comentaris d'actualitat, November, 1951, 224-226.

${ }^{10}$ Cucurull was a reader of Pedrolo and his library contains the following works by the latter: Domicili provisional, Es vessa una sang fàcil, Estrictament personal, Les finestres s'obren de nit, L'inspector arriba tard, Míster Chase, podeu sortir, Un món per a tothom, El premi literari i més coses, Un amor fora ciutat, Cròniques colonials, Cròniques d'una ocupació, Mossegar-se la cua, Violació de límits. I am indebted to the librarian Mercè Cussó for this information (Biblioteca Pública Fidel Fita d'Arenys de Mar).
} 
Pedrolo's "guiding literature" took the form of newspaper articles. Through his collaboration with the media, which we will analyse subsequently, the writer offered his reflections and expressed attitudes mostly related to the subordinated political status of his compatriots. There is, therefore, one Manuel de Pedrolo who is valued for his interventions in the media.

This hypothesis, however, does not reflect the true picture. What we might call Pedrolo's "engagement" started significantly earlier. Although in the 1940s he established a connection with Catalonia through poetry, which he understood as linguistic research and a means of self-knowledge (Ortís i Fernández, 2001: 26-27) it was in the first half of the 1950 s and the 1960 s that he really defined his criteria regarding the social function of literature.

In an interview with the journalist Sergio Vilar in 1964, Pedrolo, who was by now a recognised author of works of theatre and literary cycles, expressed the basic requirements for writing: autonomy and criteria that are independent from the political regime. Certainly these qualities, which were also defended by essayists such as Joan Fuster Ortells, influenced Pedrolo's thinking about the circumstances in which people lived. At the end of the 1980s Pedrolo synthesized his ideas on creative independence and concluded that "a culture is only alive to the extent that is conflictive". ${ }^{11}$

This conflict was made clear in Cartes a Jones Street [1968 (1978)], the tenth novel in the "Temps Obert" series. The book makes explicit the connection between Pedrolo's alter ego, Daniel Bastida (representing the literary world) and the socio-political when he wrote to Joan Peralta between May 1967 and July 1968 to explain his literary evolution in terms of his stance towards the culture and politics of the country. In fact, the narrative serves to shed light on debates that started taking form in the 1960s around ideas and events such as bourgeois nationalism, the direction taken by organisations such as Òmnium Cultural on reopening, leading political revolutionaries (the assassination of Che Guevara), and the relationship between Christianity and Marxism. It also describes the first meetings held by Bastida and Peralta in secret locations (an example of informal cultural sociability) to communicate some of these ideas and events to a small circle of people (letter dated 4/8/1967). It should also be noted that a letter dated 13/9/1967 (99-105) revealed the demonstration and repression during the 11th September commemoration attended by Pedrolo and the fine handed down to him by the government for having signed an open letter against the police's use of violence on that day (letter dated 25/9/1967).

Expressing opposition to official political ideology was a feature that he would keep even during the post-Franco period after 1975 and the emergence of Catalan autonomy (1976-1982). Pedrolo's other political interventions, until the end of his collaborations with the Avui newspaper (1989), reflect sustained criticism of two simultaneous forms of repression that fed into each other, namely national repression and class repression. He particularly voiced this criticism in relation to the subordination of Catalonia, of the Catalan-speaking countries, to the Spanish and French states, and he denounced the officialdom of Catalan autonomy (itself derived from Spanish bureaucracy) and its inability to overcome this double extortion (Ginés, 1991: 23-24). According to Pedrolo, the creative individual (to use Fuster's terms) must be solitary whilst also displaying solidarity; in his position as a citizen he has to participate in the situation experienced by the majority, and his literature has to be a qualitative medium that uses its capacity for social intervention. ${ }^{12}$ Pedrolo relates a works' level of internal complexity to its capacity to mirror a social and political situation. In this regard, he asserts that the writer must experience the present while keeping his eyes on the future, because this is the only way that his work can capture the social and cultural changes (and continuities) of an era. He goes on to say that a literary work does not need widespread social acceptance. Without falling into the trap of snobbishness or elitism, the work's message can be spread by a small core of initial readers: a "minority". Despite this, Pedrolo reiterates that the writer must first have accepted the need for social commitment, the criterion through which he produces literature:

\footnotetext{
${ }^{11}$ Pedrolo, 22-X-1988 (1992: 246).

${ }^{12}$ Josep Faulí wrote an accurate portrait of Pedrolo in which he emphasized "his indomitable commitment to writing, or the decision to write to subsist, or the desire to write novels to serve others [...]. Self-critical and demanding. Solitary but praised $[\ldots]$. And the final great dissatisfaction. As always: that's not it. From literature to politics, from writer to citizen [...]. Who can put limits on the ambitions of man?" Citation in Faulí (2007: 154).
} 
This does not mean that his work is of a lower quality or that he betrays his ideals by producing saintly social tracts, because it is through these ideals, or more precisely, by means of these ideals that the artist serves his peers, offers them a something that ennobles him rather than degrades him.

The writer must not remain hidden "behind" social events, he must not be anachronistic, instead he must be playing a central role; this is how he forms part of an advanced section of society that is looking to the future:

The artist, therefore, joins the most advanced group, which for the moment may consist of few people, but which over time, thanks to an irreversible process, is destined to inform the lives of an entire people [...]. I find art that does not also aspire to have social presence singularly frustrating [...]. A social presence is inevitable from the moment in which the artist lives in a certain social context and addresses himself to other men who, like him, are destined to live in society [...]. For me, it is not a question of knowing whether society deserves our efforts, but rather of recognizing that, as men, we cannot deny society our work.

This, according to Pedrolo, was the general "model" on which the relationship between literature and society was founded, a perspective that finds parallels in Vilar's volume of interviews with writers such as Alfonso Sastre, Gabriel Celaya and M. Aurèlia Capmany. ${ }^{13}$ This discourse was obviously applied to the specific situation of Catalonia. For this reason Pedrolo states:

I think that my work fits fully into the society in which we have to live because it reflects current ways of feeling and thinking, it responds to current concerns and exposes problems that, in reality, affect everyone a little". The solitude he refers to in this interview alludes to the situation in which writers writing in Catalan found themselves; that is they were "well aware that we are denied a whole series of means for disseminating our work that are freely available to those writing in other languages. (Vilar, 1964: 264, 267, 269)

Pedrolo's stance in this regard can be seen when he chooses to "sacrify" his work for a society that wants to be more human "I place the liberty of our people above my work", and "no definitive liberty can harm it". ${ }^{14}$

\section{Political and National Freedom}

Pedrolo's nationalism came from his family background, in which his father, Manuel de Pedrolo i d'Espona, was an active member of Acció Catalana (Catalan Action) in Tàrrega. The fact that he lived in a politicised environment caused him to feel that his "Catalaness was instinctive: even though nobody bothered to teach me Catalan". 15

In the 1930s, when Pedrolo was studying at the Escola Pia in Tàrrega, he first started to show his interest in the social role of literature when he participated as the cultural representative of a sporting society, the Tarregan

\footnotetext{
${ }^{13}$ Regarding Spanish intellectuals, it is worth noticing Pedrolo's opinion of the Falangist Dionisio Ridruejo. Pedrolo had read his book Escrito en España. He rated Ridruejo's ideological evolution as "one of the most notable, if not the most notable of all that we have witnessed in the last thirty years or so. It reassures us of his honesty and of his conscience, which led him to put on the line a position that others would have tried to preserve, whatever the consequences for other people; he chose prison and exile". At the same time he gave his opinion of Ridruejo, immediately after Franco's death in 1975, when he "entered" Barcelona with Francoist troops: "it says a lot in favour of the man that in 1939 thought that our people deserved a minimum of respect. There are Catalans who have forgotten this". This evaluation came from a comparison between Ridruejo and the so-called "Catalans from Burgos", that is, Catalans who collaborated with Franco. Pedrolo considered the latter's attitude to be far more serious than Ridruejo's political evolution. See "Encuesta Dionisio Ridruejo visto por los escritores catalanes [Ferrater Mora, Marià Manent, Manuel de Pedrolo, Francesc Vallverdú]", Destino, 1970, 29 June/5 July 1975, 31. The questions asked were: a) how do you see Dioniso Ridruejo as a writer and poet? b) how would you judge Dionisio Ridruejo's political evolution? c) do you think that Dionisio Ridruejo understood and knew the problem and culture of Catalonia better than most Castilians? Pedrolo's answers to the questionnaire have provided the citations above and have never been published in Catalan.

${ }^{14}$ N. Escur (1987: 36); Pedrolo (1999: 152).

${ }^{15}$ For more on Pedrolo's early life and his intellectual evolution, see the useful interview by Solé [1983 (2014)]. An incomplete version, "Manuel de Pedrolo", was first published in the journal L'imprès, 1, September 1983, 23-27.
} 
Students Union (1933), between October 1934 and February 1935. ${ }^{16}$ Three years later, we find Manuel de Pedrolo in Barcelona (1935-1936 and 1936-1937) as an active member of the National Federation of Students of Catalunya and the Catalanist Students Union. ${ }^{17}$ Also, in 1935 the young student participated in what was his first 11th of September commemoration. ${ }^{18}$ We do not have any more information on Pedrolo's political activities other than that when the Civil War broke out in July 1936, he is registered as a member of the Iberian Anarchist Federation (FAI). This affiliation was, he stated, a certain response to the centralising political stance of his father in Acció Catalana.

The cultural rupture of the post-war period was a decisive influence on Pedrolo's Catalanism. He became increasingly in favour of Catalan independence as a result of the Franco-Falangist occupation and began reading "everything that they had never taught, such as the History of Catalonia and the relations we have had with Castile". From the start, therefore, he developed an "intellectual awareness" that "made me a supporter of independence, which daily practice reinforced":

This situation, if there is a minimum amount of reflection, immediately leads you to certain conclusions, one of which is that a people with their own culture can never prosper as long as they are governed by another people with a different culture. It seems fairly obvious to me that such a situation is going to foster a desire for independence. ${ }^{19}$

In the first half of the 1940s up to March/April 1944, Pedrolo wrote a series of patriotic poems entitled "Poema d'una terra petita", which was published for the first time in the journal Canigó (March, 1983). ${ }^{20}$ The 1940s may be defined as a period of "patriotic resistance" given that political ideals were manifested in the act of writing in Catalan and because literary ideals went hand in glove with political ideals in both Spain and Catalonia, which were "two different societies, with different projects, two different cultures". ${ }^{21}$ This general stance was made explicit in an interview with the newspaper El Correo Catalán after Pedrolo had been awarded the Prize of Honour in 1979. Pedrolo stated "Catalonia is my land; I have no other. Yes, I have supported independence since the end of the war". ${ }^{22}$

The aforementioned series of 11 poems both evokes the past and looks to the future ("L'aurora"). It is a memoir of a place that he does not name but which seems to be Tàrrega. This place of memory allows Pedrolo to examine existence under occupation and, at the same time, reveals an emerging emancipation:

"long vexatious memories / and rows of triumphal arches: / hatreds anchored in the flesh / from the other side of frontiers // A people sleeps, a people lives / and ash fills my mouth, / and the ash lingers on my lips / poisoned by the enemy. // I know that I belong to this land: / all my dead are scattered there, / patient it awaits me and draws me to it / and, on resting there, I want to make it mine. // Let the senyera [Catalan flag] fly forever / the four stripes of blood, / above the bones resting in peace / let the footprints be friends. // A people sleeps, a people lives / and the ash lingers on my lips / poisoned by the enemy. [...]. // We have known other destinies / at the hands of legendary fathers, / we have known other misfortunes / at the hands of invading peoples [...].//

The aurora now searches for the roofs / with fingers feverish with hope, / the aurora goes from roof to roof under the gaze of the oppressed".

In the 1950s, Pedrolo's support for independence was expressed in articles on the evolution of contemporary literary history in the first half of the 20th century and, indirectly, through his linguistic demands: "The best of our [writers] remain loyal to the Catalan language, despite the general indifference". ${ }^{23}$ In 1953 Pedrolo confessed

\footnotetext{
${ }^{16}$ Garcia (1997a: 26). Also, Torrebadella (2011: 437, 449).

${ }^{17}$ Letter from Pedrolo to childhood friend from Tàrrega, Jaume Anglí (Barcelona, 3 December 1936) in Garcia: (1997a: 25). Also, Ginés (1991: 19)

18 Pedrolo (1978: 56-57). The ceremony in front of the Rafael Casanova moment led to a demonstration that went from the Plaça Urquinaona to the Passeig de Sant Joan and was dispersed by mounted police charges. Brunet (1977: 16).

${ }^{19}$ See the interview with Sardans (1985: 15).

20 (Pedrolo: 1996, 737-741).

21 (Nogués: 1979, 9).

22 (Pàmies: 1979, 19).

23 (Pedrolo: 1994, 159).
} 
to Jaume Angli that one of the things that motivated his literature was an "induced patriotism", that he did not have a "rational" belief in the homeland. It was an implicit affiliation to identity and it was conceived as an "instinct for revolt", "that just works and does not listen to reason". ${ }^{24}$

Pedrolo's theoretical knowledge regarding national and social questions was considerable. His library contained writings by Josep Fontcuberta (La batalla de Prats de Molló), Alfons Maseras (La República Catalana), Casals i Arrufat (Catalunya, poble dissortat), Manuel Cruells (El sis d'octubre a Catalunya), Antoni Rovira Virgili (Història dels Moviments Nacionalistes and Els darres dies de la Catalunya republicana), Andreu Nin (Els moviments d'emancipació nacional), Ramon Raïc (Parlar en català als Pä̈sos Valencians), Diccionari de les ciències de la societat als Pä̈sos Catalans, Aportació a la història política, social i nacional de la classe obrera a Catalunya (Unified Socialist Party), Antoni Peyrí (El problema Catalunya-Espanya), Petit llibre roig dels estudiants catalans (Catalan Revolutionary Youth Movement, 1973), Josep Guia (És molt senzill: digueu-li Catalunya), Fèlix Cucurull (Orígens del federalisme catala, Catalunya nació sotmesa, Consciència nacional $i$ alliberament), Manuel Serra i Moret (Ciutadania catalana), Pere Foix (Apòstols i mercaders), Albert Pérez Baró (30 meos de col-lectivisme a Catalunya). He also received clandestine publications from the National Front of Catalonia (Ara), ${ }^{25}$ Lluita (Independentists of the Catalan Countries and Socialist Party of National Liberation), [Nous] Horitzons (Unified socialist Party) (1,1960-32,1976), Socors Català.

Pedrolo's also worked to promote the Catalan nation and its culture abroad in the arts supplement of the Portuguese weekly A capital. Pedrolo collaborated with this publication through Fèlix Cucurull, who was an acquaintance of its director, Manuel Amaral. In these writings he evaluated the cultural rupture caused by the Spanish fascist occupation in 1939, basing himself on the book by the Mallorcan essayist Josep Melià, Informe sobre la llengua catalana, and reviewed the latest aesthetic trends up to 1970. His conclusion, after the publication of his monograph on Catalan culture in the journal Cuadernos para el diálogo (1970) ${ }^{26}$ was a certain "hope", that might permit understanding and comprehension, although this was only to be achieved on the basis of respect.

The writer's stances in these articles reveal an evolution in his thinking about Catalan nationhood; not only do they show his opposition to a fascist political regime, they also highlight the ideological and cultural foundations of an alienated society.

These elements emphasise his firm commitment to independence by the 1970s. This does not mean that he did not hold similar views prior to this decade, but in terms of language (and meaning) the 1970s are when he most strongly argues in favour of independence and describes what a break from a repressive power structure would mean politically. In this regard, Pedrolo's Marxist thinking helps him to "read" the problem of the Catalan nation as a class dialectic connected to a political status, which in turn leads him to his support for Catalan independence. Pedrolo exemplified the communication and synthesis between Marxism and the Catalan national problem that fomented a new socialist independence movement during the 1960s and would eventually result in the founding of the Socialist Party of National Liberation in 1969.

During this period, Pedrolo's thinking about the nation was a way of entering a certain reality. The nation was not a geographic or "technical" fact but rather a consequence of human activity. It was an ideal blended with social practice, a practice that distanced Pedrolo from bourgeois nationalism and imperialist concepts and led him to call for a re-founding of (cultural) "natural communities" free of class or colonial exploitation and not for "institutionalised nationalities". ${ }^{27}$

The common aims of ending class oppression and ending national oppression led him to adopt socialism as a comprehensive strategy for achieving class freedom. At the end of the 1960s the idea of mixing Marxism and

${ }^{24}$ (Garcia: 1997a, 172). Letter from Pedrolo to Jaume Anglí (Barcelona, 8 April 1953).

25 Alvar Valls secretly gave Pedrolo propaganda from the Front in the Sant Antoni Market in Barcelona between 1972 and 1975 (information obtained by email on 27 January and 2 July 2015).

${ }^{26}$ (Pedrolo: 1970b, 1-2). The monograph was entitled Cultura Catalana and appeared in Cuadernos para el diálogo ["Colección Los Suplementos"], a collaboration between 19 intellectuals, including Sanchis Guarner, Joaquim Marco, Maurici Serrahima, Frederic Roda and Joan Oliver: Cultura catalana: perspectiva 70, Edicusa, Madrid, 1970, pp. 5-70.

${ }^{27}$ (Coca: 1973, 26). 
Catalan independence was, for Pedrolo, vindicated by the popular uprising in Czechoslovakia against Warsaw Pact troops in 1968:

"I have always thought that the doctrines of Marx and nationalist theory could be combined, and this is being confirmed by the countries behind the Iron Curtain". ${ }^{28}$

Pedrolo did not regard socialism as oppressing stateless nations because he did not think that socialism annulled identity; on the contrary, he thought it was a key element of an identity that connected with the cultural meaning of the (marginalised) language because man's command of the world was essentially verbal, which implied that languages living under normal conditions were better able to interpret reality. As a result of this thinking, Pedrolo argued that the struggle should be for a new transitional society on the path towards communism.

"a system that has abolished or that proposes to abolish the exploitation of a man by another man and of a people by another people. I reject any form of personal or community colonialism. I believe, therefore, in a classless society where the individual does not live in subjection to another's will, where he is in charge of his means of production and where he can live a free and full life, without the present-day vexations". ${ }^{29}$

These thoughts were expressed in "Conjectures" de Daniel Bastida [1969 (1980)], the eleventh book in the "Temps Obert" cycle, which depicts the political movements and ideological currents in Catalonia during the second half of the 1960s and is thus related to Cartes a Jones Street. In this regard we should highlight the criteria of Ramon Planells, the writer "created" by Daniel Bastida regarding the relationship between literature, language and national belonging (pp. 166-167) and, crucially, the link between Marxism and nation. This relationship is debated with an old communist member of the Unified Socialist Party, Blanquer, who initially maintains that nationalism was the enemy of the proletariat because the struggle was not between states and nations but rather between classes, but this view evolves through debate with Planells and through knowledge of the leading communist thinkers of Marx, Engels, Lenin and Luxemburg. The dialogue between both ultimately makes clear the complementary nature of Marxism and national independence movements. However, this is circumscribed in a general understanding of Marx's ideas, which were not, according to Blanquer, based on Economism. This fundamental feature leads Planells to express an view defended by Pedrolo:

"I maintain that we are colonised. Not only economically but also culturally [...]. I accept the internationalist tendencies of Marxist thought, but I do not understand internationalism to mean that weak peoples should be placed under the control of the strong, that is, it should not establish universal control by certain nations who, as a result of this, automatically become colonialists" (pp. 87, 201).

The emphasis on individual cultures indicates the maturity of the communism defended by both protagonists, who reiterate the idea that socialism, without rejecting the Soviet example, should reflect the characteristics of each social group, which prompts Blanquer to describe (as Pedrolo himself did) how a path towards socialism could be constructed in Western society (p. 95). The novel's main achievement is to show that the social revolutionary debate is a direct manifestation of the fact of Catalan nationhood; that is, they are one and the same struggle. And for this reason, historical materialism also plays a central role.

Pedrolo's views on nationalism, as expressed in the article "Marxisme i nacionalitat" (1970), were defined, therefore, by his knowledge of the theories of leading Marxist thinkers from the 1st and 3rd Internationals ${ }^{30}$ and by the thinking of African anti-colonialists such as the Senegalese historian and anthropologist Anta Diop (19231986). In addition to arguing that each nationality should have its own specific form of Marxism, Pedrolo asserted that "oppressive nationalism" should not be identified with national and anti-colonial liberation movements. That is, socialism should not be an agent for state pan-nationalism:

\footnotetext{
${ }^{28}$ (Vidal i Gayolà: 1968, 8).

${ }^{29}$ Interview with J. M. Mas and M. Ludevid in (1971), in Pedrolo (1974a: 155). For the relationship between language, culture, socialism and national oppression, see the letters between Pedrolo and a reader, Cristina Llansana (Barcelona, 8 and 21 May 1974), in Garcia (1997b: 706-709; 711-714).

${ }^{30}$ According to Pedrolo, he was first introduced to Marxist ideas when he joined the Exèrcit Popular (People's Army), although he disagreed with what these theories had to say about nationality.
} 
"Destruction is not one of the ultimate goals of socialist thinking and, therefore, only socialism's degenerate forms can defend states created so artificially from the ribs of smaller or more peaceful nationalities that have been sacrificed to the mentality of a privileged class which has divided the world into possessors and the dispossessed, without recognising that everyone has the right to fruits of his labour and of his culture". ${ }^{31}$

The link between Marxism and Catalan nationhood explains, therefore, Pedrolo's support for independence, because it:

"evokes the sense of freedom that each person wants, on the individual and the collective levels, in order to grow and survive, to exist. Nobody willingly enters into a relationship of dependence, everybody wants to be independent, even in their private lives. It seems to me that this is a quite general and important human feeling". ${ }^{32}$

Pedrolo blamed the inability to achieve independence on Franco and the general lack of political freedom. He used the press to give a voice to that political sector that did not have one, namely those who were fighting for independence. For Pedrolo, liberty had to be liberty: national liberty was the expression and objective of this struggle. He stated this to Jordi Coca when he put forward a duel critique of the attitudes held by the contemporary conservative classes in the country (whose Catalanism was that of Prat de la Riba and the Regionalist League) and of the attitudes of external groups (almost always the political elite of the Spanish state) who prevented the construction of the Catalan nation. Pedrolo's ideal of Catalonia was that it would be for everybody. It should remembered, however, that these beliefs were viewed at the beginning of the 1970s:

“[...] when I am talking of Catalonia, I'm referring to a Catalonia for everybody, and when I speak of Catalan culture, in its broadest sense, I mean the culture of the people; not of some privileged group. And I believe, therefore, that one must criticise anything that works against this, everything that makes this difficult to achieve, whether it is from within Catalonia or from outside". 33

In an interview with the Unified Socialist Party's mouthpiece, Treball, on 11 September 1979, Pedrolo stated that, with the looming referendum on the Catalan Statute of Autonomy, the strategic goal should be complete liberty:

"All liberation ideologies, he said to the interviewer Josep Montalà, have to understand that freedom must be total: class freedom, national freedom, racial freedom, gender freedom... You cannot support one form of freedom that works against another freedom, and if that happens, the man who defends such a state of affairs is an impostor who doesn't believe in any form of freedom."

Thus, complete freedom had to include cultural freedom and national freedom, a view also aired by Josep Tarradellas at the beginning of his presidency of the provisional Catalan Government: "I believe that Catalan culture cannot exist in a state of complete normality until the moment that we no longer depend on Madrid for anything, until the Catalan Countries are fully independent ".

\section{An uncomfortable and conflictive voice}

Independence, according to Pedrolo, was a means of achieving political normality in a Europe that ultimately needed to be a collection of peoples and cultures free of any form coercive or repressive institution; that is, without states. And the Catalan Countries had to have their rightful place in this Europe. Ideologies and programmes had made the organisation of a new society a reality. Hence Pedrolo's view of socialism as a

\footnotetext{
31 (Pedrolo: 1974b, 156).

32 See the interview conducted on the fifteenth anniversary of the publication of the Mecanoscrit del segon origen in Pairoli (1988: 9).

${ }^{33}$ (Coca: 1973, 89).
} 
strategic path towards social liberation. This, in short, is the reason for Pedrolo's rejection of nationalism, which he regarded as a type of regionalism that merely reformed the Spanish state's power structures. ${ }^{34}$

However, Pedrolo's patriotism was grounded on ideas more than on political activism. It took the form of political criticism aimed essentially at a Catalan state built on autonomy. He was continuously dismayed by the lack of unity among the various independence movements and the challenges faced by these movements on being rooted in sections of society that in practice had ceased to be represented by conservative regionalism and by social democracy, both of which leant increasingly towards liberalism and Spanish nationalism.

Pedrolo expressed this idea after the regional elections on 29 April 1984 in the article "No us enganxeu els dits" (Avui, 17 May 1984), in which he states that one of the first tasks was to "free ourselves from our own internal deology" to prevent from paralysing something that after all was supposed to be a "movement" (perhaps referring to the recently created Movement for the Defence of the Land?). For this reason, Pedrolo urged people to maintain a certain flexibility in relation to the political situation. It is worth pointing out that this view was supported by the independence activist Àlvar Valls, who in a letter to Pedrolo ([Barcelona] dated 17 May 1984) agreed with Pedrolo's assessment of the independence movement at the time and with the need to broaden the support-base of the organisation to include left-wing nationalists, independence supporters in non-independence organisations, and organisations actively seeking independence, such as the Socialist Party for National Liberation, the Independence Movement of the Catalan Countries and the Movement for the Defence of the Land. Such a synthesis would in theory lead to a Catalan Nationalist Party.

Pedrolo's opinion prompted a brusque response from Carles Castellanos. In an article entitled "No n'hi ha prou amb el sentiment" (Avui, 8 July 1984), then a member of the Independence Movement of the Catalan Countries, he said that the independence movement had been under construction since the 1970s and that, rather than the sentimental theories put forward by certain intellectuals, it was more important to be clear about the strategic objective; namely not merely a change of government, but rather a struggle against the occupying State and it apparatus of domination.

This debate reveals Pedrolo's views on the actions of political organisations. Despite this, we must still question whether both stances were antithetical and, therefore, whether Pedrolo's theoretical reflections were also a political position. It can certainly be concluded that both had points in common.

Acknowledgements. The present article is part of the research conducted by the research group on Ideologies and Society in Contemporary Catalonia (ISOCAC) (2014 SGR 770).

\footnotetext{
${ }^{34}$ See the exemplary article by Pedrolo, "Nacionalisme versus independència" (Avui, 24-I-1985) in which he implicitly comments on the political resolution taken at the 7th Conference of the Catalan Democratic Convergence Party (Barcelona, 11 to 13 January 1985), which approved of the strategy of the recently founded Spanish Democratic Reformist Party. Also revealing is an interview with Pere Cullell: "Manuel de Pedrolo: ateu, marxista heterodox i independentista", El Món, 156, 19 April 1985, pp. 25-27. The article and the interview can be found in Pedrolo (2000: 155-157; 263-271).
} 


\section{References}

Albó, I (1986). Fèlix Cucurull. La lluita per l'autenticitat, Barcelona: Llar del Llibre.

Arbonès, J., Carbó, J. (2014). Epistolari Jordi Arbonès \& Joaquim Carbó, Lleida: Punctum.

Brunet, J.M (1977). "Manuel de Pedrolo: notícia de una utopía” Diario de Barcelona, 27 March, 16.

Capmany, M.A. (1957). "Reixes a través”. In: J. Sarsanedas (coord?), Cita de narradors, Barcelona: Editorial Selecta.

Cisquella, G., Erviti, J. L., Sorolla, J.A. (1977). Diez años de represión cultural. La censura de libros durante la ley de prensa (1966-1976), Barcelona: [Agrupació d’Editorials].

Coca, J. (1973). Pedrolo perillós? Converses amb Manuel de Pedrolo, Barcelona: Dopesa.

Cultura catalana: perspectiva 70 (1970), Edicusa, Madrid.

Dolç, M. (1968). "La nueva realidad de Manuel de Pedrolo", La Vanguardia española, 18 April, 63.

Escur, N. (1987). “Pedrolo: ‘Tots els temps són dolents””, Diari de Barcelona, 17 May, 36.

Faulí, J. (2007). Catalans de biaix. Ni són tots els que hi ha, ni hi ha tots els que són: simplement hi ha els que hi ha, Barcelona: Editorial Mediterrània.

Garcia, X. (1995). Pedrolianes, Ajuntament de Tàrrega: Natan.

Garcia, X. (Ed.) (1997a). Epistolari Manuel de Pedrolo I, Lleida: Ajuntament de Lleida, Udl, IEI.

Garcia, X. (Ed.) (1997b). Epistolari Manuel de Pedrolo II, Lleida: Ajuntament de Lleida, UdL, IEI.

Ginés, M. (1991). "Manuel de Pedrolo. Apunts per a una biografia”, Serra d'Or, 383, November, 23-24.

Maria Pàmies, J (1979). "Sóc independentista, marxista i els premis no m’agraden”, [Suplement], 210, El Correo Catalán, 26 May, 19.

Nogués, J (1979). "Pedrolo, la lluita per un aire més respirable al país”, Avui, 25, 9.

Ortís i Fernàndez, J.: Aproximació a l’obra poètica de Manuel de Pedrolo, Ajuntament de Tàrrega: Natan, 2001 .

Pairolí, M (1988): “Manuel de Pedrolo. Explorador de territori literaris”, Presència, 854, 3 July, 9.

Pedrolo, M. (1967). Introduction to J. Kerouac. In: Els pòtols místics, Barcelona: Proa.

Pedrolo, M. (1970a). “Beckett i Kerouac”, Serra d'Or, 124, January, 51-52.

Pedrolo, M (1970b). "Breve noticia sobre a Cultura Catala”, A Capital. Literatura \&Arte, 2 September, 1-2.

Pedrolo, M. (1974a). Si em pregunten, responc, Barcelona: Proa.

Pedrolo, M (1974b). Els elefants són contagiosos, Barcelona: Edicions 62. 
JOCIH (2016) pp.107-121 DOI: 10.1515/jocih-2016-0009

Pedrolo, M. (1978) . “Breus records de l'onze de setembre”, L’Avenç, 7-8, September, 56-57.

Pedrolo, M. (1980). Avui es parla de mi, Barcelona: Edicions 62.

Pedrolo, M. (1992). Darrers diaris inèdits, Blocs 1988-1990, Barcelona: Edicions 62.

Pedrolo, M. (1994). El llegir no fa perdre l'escriure, Lleida: Pagès editors

Pedrolo, M. (1996). Obra poètica completa, II, Lleida: Pagès Editors

Pedrolo, M. (1999). Diari 1987 [note from 9 May 1987], Barcelona: Edicions 62.

Pedrolo, M. (2000). Cal protestar fins i tot quan no serveix de res, Lleida: Edicions El Jonc.

Pijuan Vallverdú, A. (2011). "Pedrolo i Sánchez de Molina, Manuel”, Diccionari de la traducció catalana, M.Bacardí, P. Gudayol (Dir.), Eumo Editorial: Vic.

Pi de Cabanyes, O.: Glossari d'escriptors catalans del segle XX, Barceloa: PAM, 2003.

Puig, A.: "Félix Cucurull, novelista y poeta", Revista Europa, 15-VII-1963.

Saladrigas, R.: “Aproximació a Félix Cucurull” [Tele/Exprés, 14-IX-1977]. In: Albó i Vidal de

Sardans Farràs, J (1985). “Manuel de Pedrolo: un independentista radical”, Regió 7, 1137, 27 April, p. 15.

Solé, J.R. [1983 (2014)]: “Tàrrega i el patrimoni literari de Manuel de Pedrolo (una entrevista profètica)", (May), La tartaneta. Històries d'un passat recent [https:// latartaneta.wordpress.com/tag/Tàrrega. Access: 11III-2015]

Torrebadella, X. (2011). "El Boom de l'esport. Ideologia i societat a l'esport targarí (1920-1937)”, Urtx, 25, 437 and 449 .

Vallverdú, J. (1967). "Manuel de Pedrolo a Tàrrega”, Tele/Estel, 49, 23-VI, 10.

Vidal i Gayolà, J. (1968). “Manuel de Pedrolo, un novel·lista en 'estat d'excepció””, Presència, 159, 20 July, 8.

Vilar, S. (1964). Manifiesto sobre arte y realidad. Enquesta entre los intelectuales y artistas españoles, Barcelona: Fontanella. 
JOCIH (2016) pp.107-121 DOI: 10.1515/jocih-2016-0009 
JOCIH (2016) pp.107-121 DOI: 10.1515/jocih-2016-0009 
JOCIH (2016) pp.107-121 DOI: 10.1515/jocih-2016-0009 